A. A. Malinovskyi ${ }^{1}$, Dr. Sc. (Tech.), Prof., orcid.org/0000-0001-9765-3494, V.H.Turkovskyi ${ }^{1}$, Cand. Sc. (Tech.), Assoc. Prof., orcid.org/0000-0003-1869-8139,

A. Z. Muzychak ${ }^{1}$, Cand. Sc. (Tech.), orcid.org/0000-0002-6330-1076, Yu. V. Turkovskyi ${ }^{2}$, orcid.org/0000-0001-7657-7031
1 - State Higher Educational Institution Lviv Polytechnic National University, Lviv, Ukraine, e-mail: malinowski@polynet.lviv.ua; volodtur@gmail.com; mAndriy@polynet.lviv.ua 2 - Individual entrepreneur, Lviv, Ukraine

\title{
PECULIARITIES OF THE REACTIVE POWER FLOW IN THE ARC FURNACE SUPPLY CIRCUIT WITH IMPROVED ELECTROMAGNETIC COMPATIBILITY
}

\begin{abstract}
Purpose. To suggest applying a converter with a characteristic of "constant current - constant voltage" for supplying electrical arc furnaces.

Methodology. The MatLab Simulink software with matrix formation of electromagnetic state equations was used to obtain mode parameters for the installation. The averaged mode coordinates $t$ for a certain interval of the furnace operation were calculated by taking into account the stochastic nature of the load based on the theory of probability.

Findings. It is demonstated that the use of the above converter allows choosing the required level of reactive power flow between the electric network and the furnace device and provides constant value of the reactive power flow due to maintaining steady current in operating modes. As a result, the voltage fluctuations are significantly reduced and phase loads are balanced. A possibility to maintain steady reactive power consumption in furnace operating modes and to influence the reactive power volume is shown.
\end{abstract}

Originality. An approach to the dynamic compensation of the reactive power of an electric arc furnace due to the device with static parameters is found.

Practical value. Applying the "constant current - constant voltage" converter allows optimizing the reactive power use and its costs and improves electromagnetic compatibility of the arc furnace.

Keywords: flicker, reactive power, dynamic compensation, electric arc furnace

Introduction. Electric arc furnaces of alternating current $(\mathrm{EAF})$ are characterized by fast-changing operation mode with significant consumption dynamics of active and reactive power. Applying traditional power supply schemes for EAF, leads to negative influence of furnaces upon the power quality of electricity in the grids of power supply systems.

The general approaches to the analysis of electromagnetic compatibility in networks with a special load in [1] are considered, there are described approaches to the solution of the power quality problems. The presence of significant power quality problems is confirmed by many experimental data.

In particular, measurements of power quality in a network with 60 MVA furnaces [2] showed the presence of low-frequency current fluctuations and high-frequency and low-frequency voltage flicker on power busbars. Experimental analysis of ultra high power furnace [3] showed significant changes in reactive and active power consumption and asymmetry for different phases of these changes. As a result, the power quality is greatly reduced; this requires cost-intensive measures and means to improve the situation.

Analysis of the recent research and publications. Dynamic operation of the electric furnace leads to a deterioration of energy performance. Therefore, it is pro-

(C) Malinovskyi A. A., Turkovskyi V. H., Muzychak A. Z., Turkovskyi Yu. V., 2019 posed to choose a rational mode, which can be the maximum allowable value that is not subject to the transfer of metal, and not the maximum value of the power of spirits [4]. It is also proposed to choose a mode that involves optimizing the furnace performance [5]. The analysis of the asymmetric furnace modes [6] shows that the voltage unbalance in the furnace power supply can reach a significant level. Arc furnaces are a significant consumer of reactive power and the amount of charge for it can be great [7].

Traditional approaches to reduce the negative electromagnetic effect of arc furnaces upon electric networks is to increase the power supply in EAF connection node, and to limit reactive power flow change through Static VAr Compensators (SVC). Often both approaches are used simultaneously. Dynamic compensation, in most cases, consists of a controlled reactoror or capacitor and an uncontrolled filter compensation device. These devices should have high performance, and therefore a lot of attention is devoted to the development of a rational management algorithm. Another important issue is the compensation of higher harmonics and the choice of the optimum power equipment.

The main negative consequence of the dynamic mode of the furnace is the voltage fluctuations in the power supply. These fluctuations are due to the significant dynamics of changes in reactive power consumption, and, to a lesser extent, the change in the consumption of active power. 
In order to reduce the voltage fluctuations, it is proposed to control the SVC on the basis of dynamic digital simulation of the full steel melting period [8] and the development of appropriate reactive power consumption forecasting algorithms, for example, using the Gray-Markov method [9].

A significant proportion of research is devoted to the simulation of an electric arc. In article [10], the simulation of the arc was performed through the dynamic parameters of its current and radius, and the simulation of the electric circle of the chipboard using Chua chaos generator. In order to study the flicker voltage [11], it is proposed to simulate the real arc characteristics and the flicker meter model.

To reduce voltage fluctuations, SVC with switching reactor [12] and switching capacitor [13], as well as static synchronous compensators (STATCOM) [14] are used. Corresponding attention is paid to the work of the SVC of the main nodes, in particular, the filters of higher harmonics [15]. Taking into account the considerable cost of the equipment of the compensating device, techniques for selecting the rational power of SVC [16] are developed.

The review shows that all attention is paid to reducing the effects of arc furnaces on the network. The possibility of reducing the level of generation of this effect by an arc furnace is not considered.

Research question. The total installed power of the dynamic compensation device may exceed the power of the furnace transformer by more than 3 times. In addition, such device aims at eliminating the consequences of EAF negative impact, without reducing the generation level of the negative factor.

Objectives of the article. A promising direction in reduction of EAF negative electromagnetic influence upon the network is applying the power supply converter with an external characteristic of changes of "constant current - constant voltage" type (CC-CVC). The characteristics of such converter within normal arc furnace modes (from operational short-circuits to nominal load) are constant in current, and within abnormal modes (from nominal load to off mode) they are constant in voltage. Characteristics' area of the converter is formed by an inductive-capacitive converter from voltage source to current source [17] in case of normal modes, and using nonlinear elements in case of abnormal ones.

A distinct feature of an inductive-capacitive transformer scheme [17] is a possibility to reduce the installed capacity of a condenser battery and avoid (or reduce significantly) the production of reactive power to the network under the conditions of inductive loading type, which is common for EAF.

The use of $\mathrm{CC}-\mathrm{CVC}$ for EAF, during arc power change, makes it possible to achieve a practically constant value of reactive power flow between the network and furnace device. In other words - to compensate for the dynamic changes in reactive power. As a result, the reactive power flow costs can decrease.

The objective of the article is to present the results of the research on $\mathrm{CC}-\mathrm{CV}$ convecter, which uses the proposed scheme of the inductive-capacitive transformer with electromagnetic coupling between the contours of the reactive elements in relation to provision of the desired level of reactive power flow between the electric network and electric furnace device. Due to this significantly decreases voltage fluctuations value in the network and aligns the loading of the phases. At the same time it affects the performance of the furnace positively.

Presentation of the main research and explanation of scientific results. The block scheme of power supply for AC EAF using CC-CV converter is shown in Fig. 1. It contains inductive (IE) and capacitive (CE) elements located between the bars of power system (PS) and the arc furnace transformer (AT). The electric arc furnace (EAF) is powered with secondary winding of this transformer. The reactants of IE and CE can be chosen according to resonant or quasi-resonant configuration. One shall take into account the influence of transformation ratio $k_{t}$ of primary windings of the transformer, to which respective capacitive and inductive elements are connected. Nonlinear elements are not shown in the scheme for clarity.

Electromagnetic processes in the given furnace power supply scheme in the loop method can be written down in the following form [18]

$$
\begin{gathered}
G R G_{t} \vec{i}_{k}+G M G_{t} \frac{d \vec{i}_{k}}{d t}+G\left(\vec{u}_{n}+\vec{u}_{c}\right)=G \vec{e}+R_{0} \vec{j}+M_{0} \frac{d \vec{j}}{d t} \\
C \frac{d \vec{u}_{c}}{d t}=G_{t} \vec{i}_{k}-C_{0} \vec{j}
\end{gathered}
$$

where is column vector of loop currents of scheme lines; $\vec{u}_{n}, \vec{u}_{c}, \vec{e}$ are column vectors in correspondence to voltage of nonlinear elements, voltages of capacitive elements and EMF of electric circuit lines; is column vector of supply sources; $G, G_{t}$ are second incidence matrix of circuit graph, combined for electric and magnetic circuit lines, and its transposed matrix; $M, R$ are respective matrices of internal and mutual inductions and active resistances of circuit lines, combined for electric and magnetic circuits; $M_{0}=G M C_{0} ; R_{0}=G M C_{0}$ are respective matrices of supply sources transformation on inductive elements and resistors; $C$ is matrix of circuit line capacities; $C_{0}$ is matrix of distribution factor for open circuit.

The study of electromagnetic processes was carried out with the help of MatLab Simulink software environment, which provides block simulation modelling of systems and devices using the technology of visual-oriented programming. When choosing the Simulink environment usage format, it was taken into account that the formed equations of electromagnetic processes (1) have a sufficiently high order, and therefore element-by-ele-

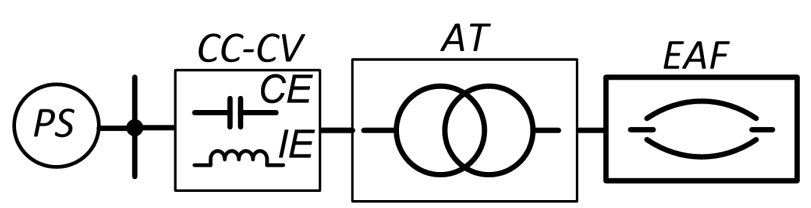

Fig. 1. The block scheme of arc furnace power supply with a $C C-C V$ converter 
ment setup of circuit equations is cumbersome and inconvenient, both during the settlement of calculation process and in the process of calculation itself. In addition, this approach complicates the introduction of changes to the main electric circuit scheme. From this perspective, we adopted a matrix format of Simulink environment usage with the help of MathLab library for numerical solution of differential equations systems andprocessing of modelling results.

Simulink schematic diagram of $\mathrm{AC} \mathrm{CC}-\mathrm{CVC}$ for EAF power supply is shown in Fig. 2. It consists of block of input data and formation of vectors column for circuit parameters (Parameters) (in which column vectors inductances $L_{v}$, resistances $R_{v}$ and EMF $E_{v}$ branch of circuit are formed), Gtmatrix block of incident matrices formation $G$ and $G_{t}$, and blocks of Mmatrix matrix and Evector vector formation parameters, blocks of matrices' multiplication, inverse matrix calculation and numerical integration with given set of conditions. The results are processed in Results block.

The scheme of one of the model's blocks, i.e. the block of formation of vectors for circuit parameters $\mathrm{Pa}$ - rameters, is shown in Fig. 3. The numerical values of input data are taken from Date block and used to form vector columns $L_{v}$ and $R_{v}$, with the help of which matrices $M$ and $R$ equation systems (1) are created later.

The block also creates a vector column of phase EMF for power supply $E_{v}$. There is also Nonlinearity block in order to account for the characteristics of circuit's nonlinear elements, which receives the values of mode coordinates via Rez input.

Numerical calculations are carried out through the example of an EAF, which relative operational shortcircuit current is 1.9 , the nominal power of the transformer is $140 \mathrm{MW} \cdot \mathrm{A}$, the network voltage is $35 \mathrm{kV}$. A scheme of $\mathrm{CC}-\mathrm{CVC}$ with phase shifting between the voltage vectors is applied to IE and CE lines, at 60 electrical degrees.

Dependences of circuit reactive elements' power on equivalent relatively resistance of the arc (received for steady-state modes) are shown in Fig. 4. Mode parameters here and hereinafter are expressed in relative units, which are based upon nominal parameters of furnace transformer. The $\mathrm{CC}-\mathrm{CVC}$ is asymmetrical with

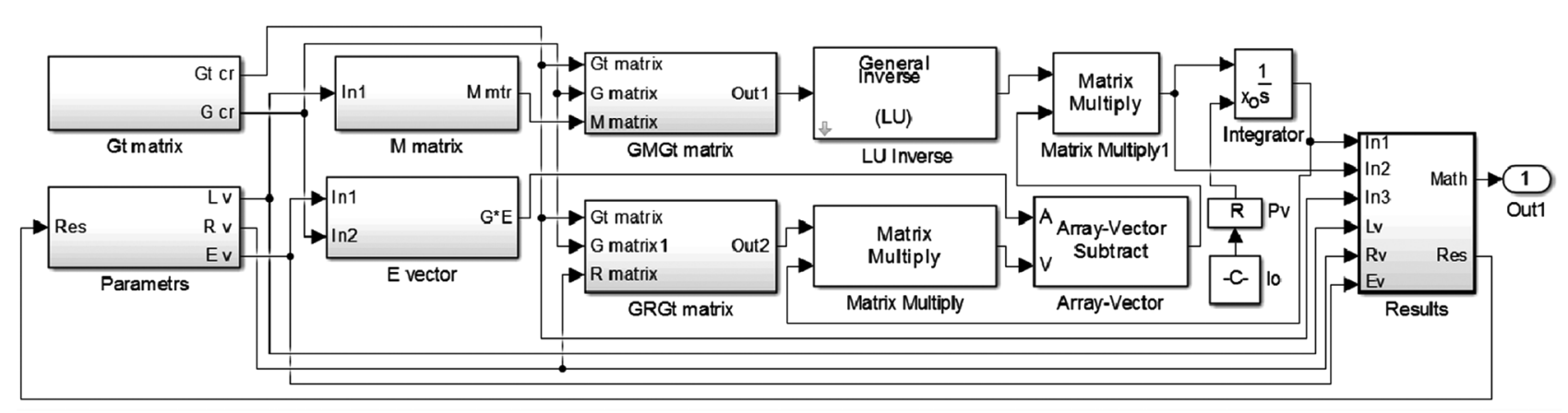

Fig. 2. Simulink schematic diagram of EAF power supply model with CC-CV converter

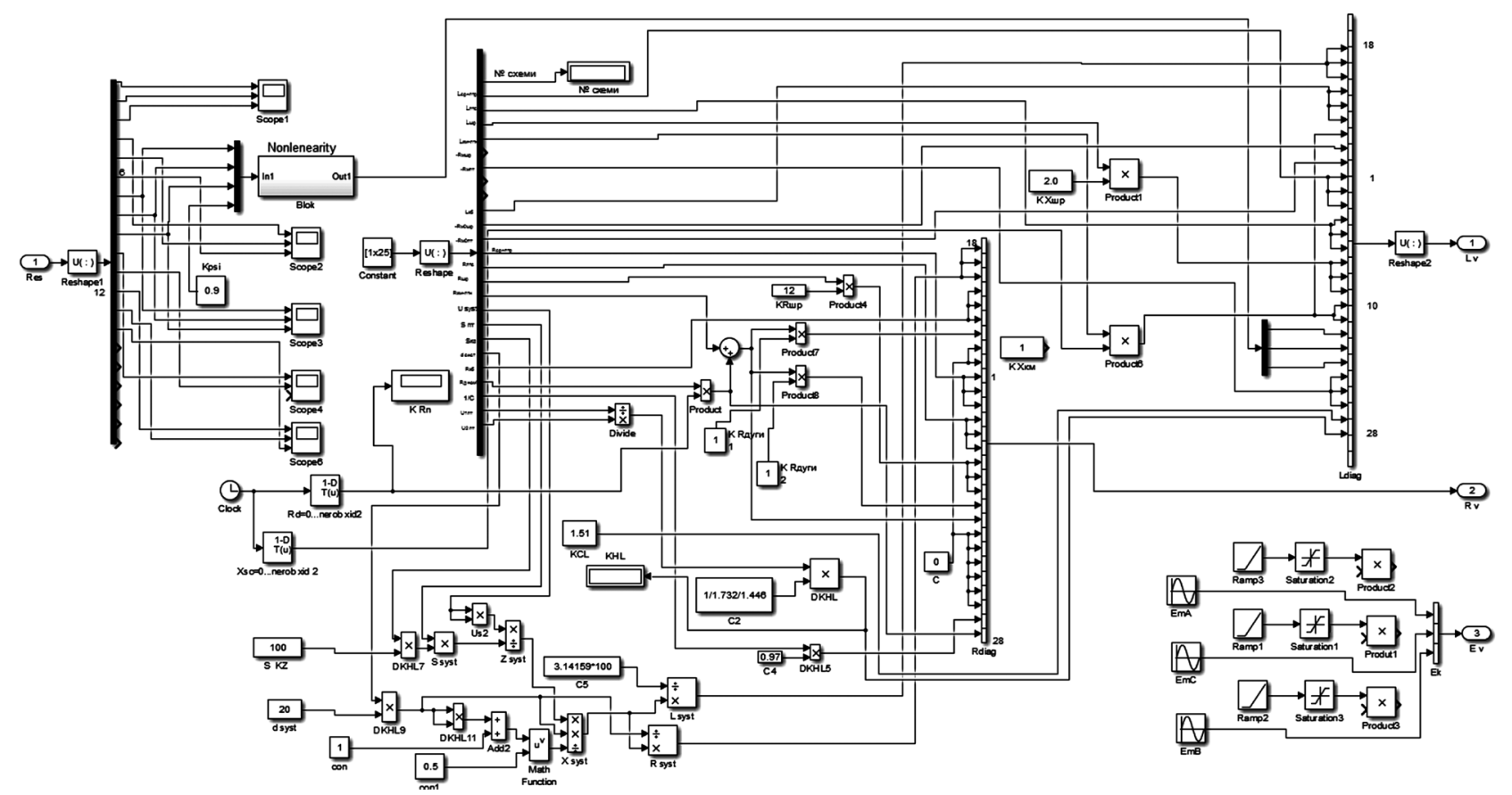

Fig. 3. Block of input data and formation of vectors for circuit parameters 


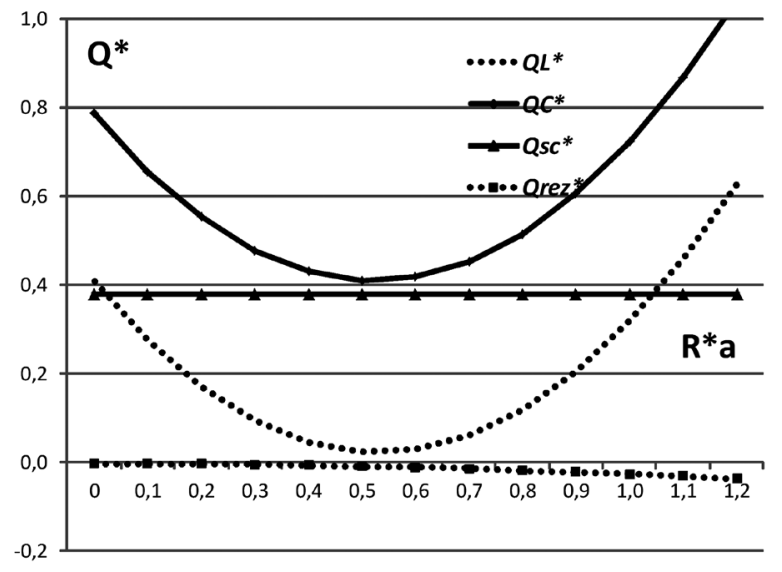

Fig. 4. Diagram of reactive elements' power change depending on load resistance

respect to the parameters of reactor and condenser battery; the transformation ratio between circuits with reactor and with condenser battery $k_{t}$ is 1.38 . The range of load resistance variation is considered typical for normal $\mathrm{CC}-\mathrm{CVC}$ operation modes, i.e. from zero (operational short-circuit) to 1.2 of the nominal load resistance.

The dependences show a change in equivalent load resistance leading to a change in reactive powers of reactor and condenser battery . This change occurs in such a way that the difference between their modules remains almost unchanged. The reactive power emitted in the load circuit that is an EAF low-voltage circuit, does not depend on the resistivity of the load. This indicates that the current in the low-voltage circuit and in the arc is constant. Hence, circuit provides stabilization of the load current for the entire range of arc equivalent changes within normal operating modes. The resulting reactive power, consumed from the network $Q_{r e z}$ equals practically zero. Accordingly, there is practically no reactive power exchange between furnace and network at the whole range of normal operating modes, so the furnace does not consume or generate reactive power.

Fig. 4 shows a slight change in reactive power consumption by only several percent due to change in load from zero (operational short-circuit) to the nominal value. We shall note that in the traditional scheme of power supply of the same EAF under similar modes, the change in reactive power consumption will be $260 \%$. Thus, CC-CVC provides a dynamic compensation of EAF reactive power due to the elements with static parameters.

Applying $\mathrm{CC}-\mathrm{CVC}$ provides constant and equal values for the arcs currents in all phases of the normal modes range. As a consequence, the absence of reactive power consumption changes $\delta Q_{\text {rez }} \approx 0$. Furthermore, the main constituent of the voltage variation swing will be close to zero. Calculations show that the maximum range of the voltage fluctuations will decrease by 4 times. In addition, the phase currents balancing eliminates asymmetric load. Hence, applying $\mathrm{CC}-\mathrm{CVC}$ improves electromagnetic compatibility of EAF with an electric network. Simultaneously, the control of arc power is simplified due to its linear changing with arc length.

As a result, $\mathrm{CC}-\mathrm{CVC}$ application leads consumer to focus on limiting the generation of negative factors instead of struggling with consequences of the negative influence of EAF on the network.

In Fig. 5 we show changes of the reactive power flow in the network, depending on the load resistance for various values of transformer windings' transformation ratio $k_{t}$. The figure shows that provided symmetric parameters of the scheme $k_{t}=1$, the device generates reactive power to the network with value of about 0.4 of furnace transformer power. If the circuit is made with $k_{t}=$ $=1.38$, then the device does not generate reactive power to the network. With the value $k_{t}=1.405$, the device consumes reactive power in the initial range of resistivity load change (about 0.02 from furnace transformer power) and generates reactive power of approximately the same values at the final range. If $k_{t}=1.55$, the device consumes reactive power at the entire range of changes. In this case, the reactive power coefficient takes values in the range of $0.08-0.05$.

As can be seen from the results obtained, the $\mathrm{CC}-$ CVC with electromagnetic coupling between the reactive elements can be designed with the regard to different nature of reactive power flow in the network, in particular, its generation or consumption, or its consumption in one range of load change and generation in another. There is also an opportunity to influence the quantitative characteristics of these flows.

The abovementioned results are true for resonant configuration of the circuit parameters. Quasi-resonant configuration creates additional options for influencing the nature and extent of reactive power flow, which can be clearly depicted by the graph in Fig. 5 with $k_{t}=1.38 n$.

According to the current Ukrainian methodology, not only the volumes of reactive power flow are important during "reactive energy" calculations for power system, but the value of reactive power coefficient $(\operatorname{tg} \varphi)$ is important as well, in particular, its average values over

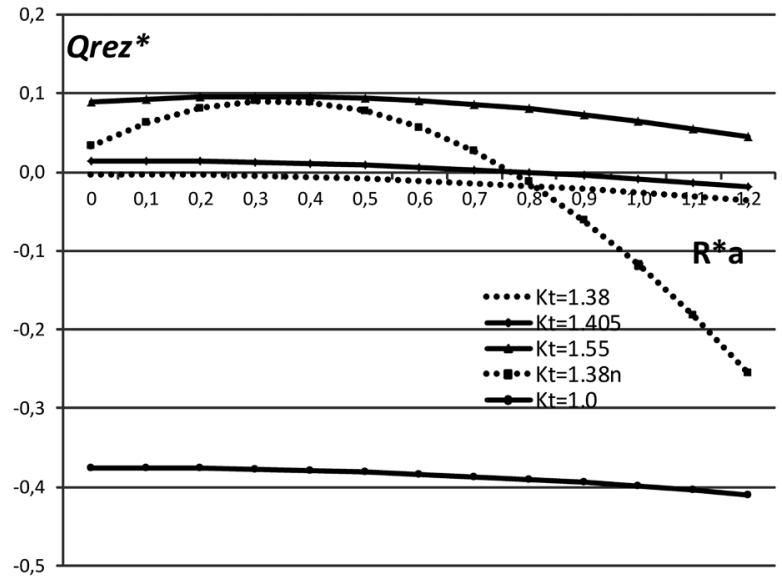

Fig. 5. Dependence of reactive power flow in the network on the load resistance 
the estimated period. Therefore, on the basis of the above data, the values of $\operatorname{tg} \varphi$ were calculated for period of normal operating mode of electric arc furnace. The results of the calculations are given in Fig. 6 for the same values of transformation ratio. As can be seen, the value of $\operatorname{tg} \varphi$ during EAF operating mode change (from operational short-circuit to nominal one) varies greatly from zero and up to values of $\operatorname{tg} \varphi$ module bigger than two. This is due to a significant range of change in active arc power, which takes values from zero to the nominal load power, notably that the specific value of the power at a certain point has a probable nature.

Therefore, the estimation of the fee for the reactive power flow should be carried out at the average values of $\operatorname{tg} \varphi$ during the melting period, determined taking into account the statistical characteristics of electric modes of electric arc furnaces.

There were received experimental statistical characteristics of arc currents and their analysis [19] for EAF with traditional power supply scheme, which corresponds to furnace supply system where $U=$ const. This showed that these currents have a normal distribution law of probability density. On the basis of these experimental data, a statistical calculation of electric mode parameters can be carried out for EAF with traditional power supply.

In the system where $I=$ const, the variable mode parameter is not the current, but the voltage of the arc and therefore, it is necessary to have statistical characteristics regarding the arcing voltage for the calculation of electrical modes. The arcing features and its probabilistic characteristics depend to a large extent on the energy emitted in the arcs. Since by equivalence conditions both power systems should have the same amount of energy, and taking into account that the physical processes in the arcing area will not change fundamentally with the transition of electric furnace to the power supply system where $I=$ const, it can be assumed that the arcing voltage will also have normal distribution law of probability density.

In this case arcing voltage probability density $f\left(U_{A}\right)$, as an unlimited (in values) random time function, has the following form

$$
f\left(U_{A}\right)=\frac{1}{\sigma \sqrt{2 \pi}} e^{-\frac{\left(U_{A}-m_{U}\right)^{2}}{2 \sigma^{2}}},
$$

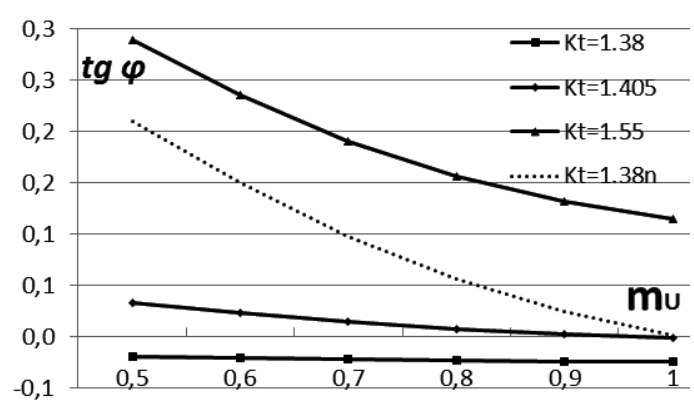

Fig. 6. Dependence of reactive power coefficient of the network on the load resistance where $U_{A}$ is the arcing voltage; $\sigma$ and $m_{U}$ are respectively average square deviation and mathematical expectation of arcing voltage.

Taking into account the actual limitation of arcing voltage range variation from zero to nominal voltage of furnace transformer $U_{2 n}$, the probability density function $f_{0}\left(U_{A}\right)$ will be determined as follows

$$
f_{0}\left(U_{A}\right)= \begin{cases}\frac{1}{h \sqrt{2 \pi}} e^{-\frac{\left(U_{A}-m_{U}\right)^{2}}{2 \sigma^{2}}}, & U_{A} \in\left[0, U_{2 n}\right], \\ 0, & U_{A} \notin\left[0, U_{2 n}\right]\end{cases}
$$

where $U_{2 n}$ is the nominal voltage of furnace transformer; $h$ is an adjustment factor.

The value of this parameter is calculated using the equation

$$
h=\frac{1}{\sigma \sqrt{2 \pi}} \int_{0}^{U_{2 n}} e^{-\frac{\left(U_{A}-m_{U}\right)^{2}}{2 \sigma^{2}}} d U_{A} .
$$

With the help of Laplace's function

$$
F(z)=\frac{1}{\sqrt{2 \pi}} \int_{0}^{z} e^{-\frac{t^{2}}{2}} d t .
$$

Numerical value of $h$ parameter can be determined as follows

$$
h=F\left(\frac{U_{2 n}-m_{U}}{\sigma}\right)-F\left(\frac{-m_{U}}{\sigma}\right) .
$$

Under these conditions, using the equation (3), there can be calculated the probability of arcing voltage values occurrence within a certain range for a given mathematical expectation of this voltage, which corresponds to arc power regulator setting. One can determine the average value of $\operatorname{tg} \varphi$ for a certain period of furnace's operating time using $\operatorname{tg} \varphi$ values in each of these ranges and the determined probabilities of occurrence of arcing voltage values in this range.

Calculations were made for ranges of values of average square deviation from 0.05 to 0.3 and mathematical expectation of arcing voltage from 0.5 to nominal. It is taken into account that probability distribution function of arcing voltage has a limited range of argument variation.

The results of $\operatorname{tg} \varphi$ average values calculation for the period of furnace's operation time with the given value of mathematical expectation of arcing voltage and with average square deviation $\sigma=0.1$ are given in Table.

As can be seen from these numerical data, the change in $k_{t}$ coefficient significantly influences the volumes of reactive power flow. So, if the value is $k_{t}=1.0$, the electric furnace with $\mathrm{CC}-\mathrm{CVC}$ generates reactive power with the values of $\operatorname{tg} \varphi$ that vary from 0.9824 to 0.41616 (capacitive nature). While $k_{t}=1.38$ is used, the furnace generates to the network a very small amount of reactive power with a capacitive value of $\operatorname{tg} \varphi$, which varies from 0.0181 to 0.027 . As it can be seen from the table data, the setting of $k_{t}$ equal to 1.405 causes a slight consumption 
Table

Dependence of average reactive power coefficient on the values of $k_{C L}$ and $m_{U}$

\begin{tabular}{|c|c|c|c|c|c|c|}
\hline \multirow{2}{*}{$k_{t}$} & \multicolumn{6}{|c|}{$m_{U}$} \\
\cline { 2 - 7 } & 0.5 & 0.6 & 0.7 & 0.8 & 0.9 & 1 \\
\hline 1.38 & -0.018 & -0.019 & -0.021 & -0.023 & -0.025 & -0.027 \\
\hline 1.405 & 0.026 & 0.016 & 0.008 & 0.002 & -0.003 & -0.007 \\
\hline 1.55 & 0.246 & 0.190 & 0.154 & 0.127 & 0.107 & 0.092 \\
\hline $1.38 \mathrm{n}$ & 0.172 & 0.108 & 0.061 & 0.024 & -0.007 & -0.032 \\
\hline 1.0 & -0.982 & -0.786 & -0.660 & -0.572 & -0.508 & -0.462 \\
\hline
\end{tabular}

of reactive power from the network in the range of values of mathematical expectation of arcing voltage from 0.5 to 0.8 and its small generation in the rest of range of change of $m_{U}$. If there is $k_{t}=1.55$, then the furnace device with $\mathrm{CC}-\mathrm{CVC}$ is a consumer of reactive power with values of $\operatorname{tg} \varphi$ in the range of $0.2458-0.092$.

Comparison of the values of $\operatorname{tg} \varphi$ in Table with the data of the graphs in Fig. 6 shows that the average values of $\operatorname{tg} \varphi$ obtained for the corresponding mathematical expectation of arcing voltage are close to the values of $\operatorname{tg} \varphi$ obtained for the actual values of this voltage (relative value of arc current equals to 1) using average square deviation $\sigma=0.1$.

The change in $k_{t}$ coefficient can be combined with the quasi-resonant configuration of the circuit parameters. Thus, using the data variant where $k_{t}=1.38$, the quasi-resonant setting allows the furnace device to be a reactive power consumer within the same range of changes of $m_{U}$ and to be a generator within the range of $m_{U}$ changes.

The obtained results show that the use of $\mathrm{CC}-\mathrm{CVC}$ can influence the volume and direction of reactive power exchange between the network and the furnace device. This allows the consumer to choose a rational usage mode that can be based on some particular index, which may be, for example, the level of payment for reactive power based on the determinant for it, which may be, for example, the degree of electromagnetic effects on the network or the level of payment for reactive power.

The results of values calculation of the reactive power coefficient in the function of mathematical expectation of arcing voltage are shown in Fig. 7. As can be seen, in case of average square value of arcing voltage $\sigma=0.25$, the highest values of reactive power coefficient for the input data belong to $m_{U}=0.5$ with respective transformation ratios of $1.405,1.55$ and 1.38 nrez. With the increase in mathematical expectation of arcing voltage (increase in voltage setting of the arc power regulator), the value of the reactive power coefficient decreases. There is practically the unchanged value $\operatorname{tg} \varphi$ for variants of input data with $k_{t}=1.38$ and 1.405 . From the diagram it can be seen that furnace operation with the nominal voltage setting of arc power regulator is characterized by better indices for reactive power flows.

The effect of average square deviation of arcing voltage on $\operatorname{tg} \varphi$ value is shown in the graphs in Fig. 8.

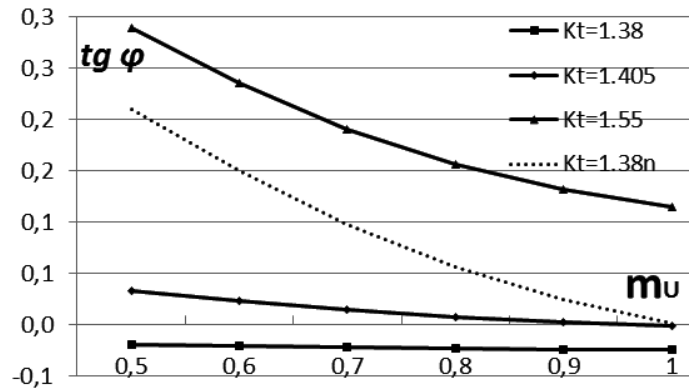

Fig. 7. Dependence of network's tg $\varphi$ in function of mathematical expectation of arcing voltage, $\sigma=0.25$

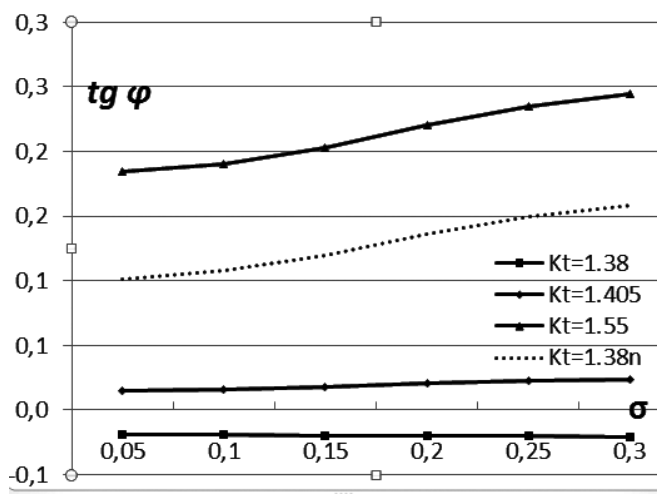

Fig. 8. Dependence of network's $\operatorname{tg} \varphi$ in function of average square deviation of arcing voltage, $m_{U}=0.6$

As can be seen from the graphs, for considered variants of the output data, with the growth of average square deviation, the expected value of reactive power coefficient module increases as well. This means that at the same arcing power, the reactive power consumed from the network or generated into it in the initial period of melting will be slightly higher than in later calmer periods of work.

The positive aspects of use $\mathrm{CC}-\mathrm{CVC}$ are confirmed by the tests results carried out on a working installation (with the capacity of $3.2 \mathrm{MW}$ ) for the supply of electrochemical production's salt-bath furnace with a dynamic load character and on a test production plant for power supply of an arc furnace with a capacity of $2.0 \mathrm{MV}$. A. The conducted test stages of electric arc furnace confirmed the possibility of CC-CVC usage for power supply of the arc furnace having dynamic, asymmetric and nonlinear load.

Conclusions. The obtained results show that $\mathrm{CC}-$ CVC usage for an arc furnace of an alternating current allows dynamic compensation of the EAF reactive power considering elements with static parameters. At the same time changing the mode from operational shortcircuit to nominal load causes a change in reactive power consumption by only a few percentages.

The proposed scheme of constant current - constant voltage converter allows influencing the volume and direction of reactive power exchange between the gird and the furnace device by changing the transformation ratio of furnace transformer's primary windings. Hence, the consumer has an opportunity to choose a 
rational mode, based on the most significant parameter, for instance, the degree of electromagnetic effects on the network or reactive power costs.

The average values of reactive power coefficient were determined, assuming that arcing voltage has a normal distribution law of probability density, while using the voltage/current transformer scheme. The average values of reactive power coefficient, obtained for the corresponding mathematical expectation of arcing voltage, are close to the values of this coefficient, obtained for the actual values of this voltage.

The volumes of reactive power flows are influenced by voltage setup of the arc power regulator and dispersion of arcing voltage. As the voltage setup increases, the reactive power coefficient decreases. The growth of arcing voltage dispersion causes an increase in reactive power consumption.

\section{References.}

1. Zhezhelenko, I. V., Shidlovsky, A. K., Pivniak, G. G., Saenko, Yu. L. and Noiberger, N.A., 2012. Electromagnetic compatibility of consumers. Moscow: Mashinostroyeniye.

2. Seker, M., Mammedov, A., Hiseyinov, R. and Kockanat, S., 2017. Power Quality Measurement and Analysis in Electric Arc Furnace for Turkish Electricity Transmission System. Elektronika ir Elektrotechnika, 23(6). DOI: 10.5755/j01.eie.23.6.19691.

3. Toma, A., Popa, G. N., Iagar, A. and Deaconu, S. I., 2010. Experimental analysis of electric parameters of a $100 \mathrm{t}$ UHP electric arc furnace. In: 2010 IEEE International Conference on Industrial Technology. 14-17 March 2010, Vina del Mar, Chile [online]. Available at: <https:// www.researchgate.net/publication/251927323_Expemental_analysis_of_electric_parameters_of_a_100_t_ UHP_electric_arc_furnace $>$ [Accessed $24 \overline{\text { December }}$ 2017].

4. Martell-Chavez, F., Ramirez-Argaez, M., LlamasTerres, A. and Micheloud-Vernack, O., 2013. Theoretical Estimation of Peak Arc Power to Increase Energy Efficiency in Electric Arc Furnaces. The Iron and Steel Institute of Japan International, 53, p. 743-750.

5. Stopar, K., Kovacic, M., Kitak, P. and Pihler, J., 2014. Electric-arc-furnace productivity optimization. Materials and Technologies, 48(1), pp. 3-7.

6. Djeghader, Y. and Labar, H., 2013. Investigation of Voltage Unbalance Problems in Electric Arc Furnace Operation Model [online]. Available at: $<$ http: //ljs.academicdirect.org/A22/037_048.htm > [Accessed 17 January 2018].

7. Deacony, S. I., Popa, G. N. and Tihtomir, L., 2010. Comparative Study for EAF's Reactive Energy Compensation Methods and Power Factor Improvement. WSEAS Transactions on Systems [online], 9(9), pp. 979-988. Available at: < https://dl.acm.org/citation. $\mathrm{cfm} ? \mathrm{id}=1865391>$ [Accessed 11 January 2018].

8. Novitskiy, A., Konotop, I. and Westermann, D., 2013. Design of Reactive Power Compensation Devices on the Base of Dynamical Simulation of Steelmaking Process. In: International Conference on Renewable Energies and Power Quality (ICREPQ'13), Bilbao, Spain,
20-22 March, 2013. RE\& PQJ, 1(11), March 2013 [pdf], pp. 1164-1167. Available at: <http://www.icrepq.com/ icrepq'13/565-novitskiy.pdf $>$ [Accessed 27 February 2018].

9. Samet, H. and Mojallal A., 2014. Enhancement of electric arc furnace reactive power compensation using Grey-Markov prediction method. IET Generation Transmission \& Distribution, 8(9), pp. 1626-1636.

10. Xu, D. and Yongming, Y., 2013. A novel AC electric arc furnace model and simulation for power quality study. Journal of Theoretical and Applied Information Technology, 49(3), pp. 887-892.

11. Estrada-Villa, G. R., Cano Plata, E. A. and UstarizFarfan, A.J., 2014. Modeling electric arc furnace to estimate flicker levels in power systems using ATP. In: 16th International Conference on Harmonics and Quality of Power (ICHQP. 25-28 May 2014, Bucharest, Romania [online]. Available at: <https://www.researchgate.net/ publication/271481855_Modeling_electricarc_furnace_to_estimate_flicker_levels_in_power_systems using_ATP $>$ [Accessed 13 November 2017].

12. Sam Morello, Thomas J. Dionise and Thomas L. Mank, 2015. Installation, Startup and Performance of a Static Var Compensator for an Electric Arc Furnace Upgrade. In: 2015 IEEE Industry Applications Society Annual Meeting. DOI: 10.1109/IAS.2015.7356881.

13. Esfahani, M. T. and Vahidi, B., 2016. Electric arc furnace power quality improvement by applying a new digital and predicted-based TSC control. Turkish Journal of Electrical Engineering \& Computer Sciences, 24, pp. 3724-3740.

14. Grünbaum, R., Hasler, J.-F. and Rasmussen, J., 2011. Statcom for mitigation of flicker emanating from a large EAF. In: $21^{\text {st }}$ International Conference on Electricity Distribution Frankfurt, 6-9 June 2011 [pdf]. Available at: <http://www.cired.net/publications/cired2011/part1/ papers/CIRED2011_0337_final.pdf> [Accessed 9 February 2018].

15. Varetsky, Y. and Gajdzica, M., 2015. Energizing arc furnace transformer in power grid involving harmonic filter installation. Przegląd Elektrotechniczny, 4, pp. 64-69.

16. Nikolaev, A. A., 2017. Development of an improved method for selecting the power of a static thyristor compensator for an arc furnace. Power engineering of metallurgy, energy saving and electrotechnical systems. Vestnik Magnitogorsk State Technical University, 15(3), pp. 74-92.

17. Malinovskyi, A.A., Turkovskyi, V.H., Muzychak, A. Z. and Turkovskyi, Yu. V., 2018. The Efficient Power Supply Scheme of Alternating Current Electric Arc Furnaces. In: 2018 IEEE $3^{\text {rd }}$ International Conference on Intelligent Energy and Power Systems. DOI: 10.1109/IEPS.2018.8559585.

18. Seheda, M.S. and Ravlyk, N. O., 2014. Limiting of internal overvoltages in electric networks of power station auxiliaries during single-phase ground faults. Naukovyi Visnyk Natsionalnoho Hirnychoho Universytetu, 6, pp. 116-119.

19. Nikolaev, A. A., Tulupov, P. G. and Savinov, D. A., 2017. Statistical Analysis of Random Fluctuations of 
Currents in the Electric Arc Steel-making Furnace for Different Melting Techniques. In: International Conference on Industrial Engineering, Applications and Manufacturing (ICIEAM), 16-19 May 2017, St. Petersburg, Russia, DOI: 10.1109/ICIEAM.2017.8076206.

\section{Особливості перетікань реактивної потужності у схемі живлення дугової сталеплавильної печі 3 покращеною електромагнітною сумісністю}

\section{А. А. Маліновський ${ }^{1}$ В. Г. Турковський ${ }^{1}$, А. З. Музичак ${ }^{1}$ Ю. В. Турковський ${ }^{2}$}

1 - Державний вищий навчальний заклад Національний університет „Львівська політехніка“, м. Львів, Україна, e-mail: malinowski@polynet.lviv.ua; volodtur@gmail.com; mAndriy@polynet.lviv.ua

2 - Фізична особа підприємець, м. Львів, Україна

Мета. Запропонувати використання для живлення дугових сталеплавильних печей змінного струму перетворювача з характеристикою „сталий струм - стала напруга“.

Методика. Для визначення параметрів режиму установки використовувалося програмне середовище MatLab Simulink із матричним формуванням рівнянь електромагнітного стану. Усереднені за певний інтервал роботи печі значення координат режиму розраховувались з урахуванням стохастичного характеру навантаження на основі положень теорій імовірності.

Результати. Показано, що використання описаного вище перетворювача дає можливість обрати бажаний обсяг перетікань реактивної потужності між електричною мережею й пічною установкою та забезпечує, за рахунок підтримання сталого струму в робочих режимах, практично незмінне значення потоку реактивної потужності. У результаті суттєво зменшуються коливання напруги в мережі та вирівнюються завантаження фаз. Показана можливість підтримання в робочих режимах печі сталого значення споживання реактивної потужності та можливість впливати на перетоки цієї потужності.

Наукова новизна. Показана можливість здійснення динамічної компенсації реактивної потужності дугової печі за допомогою пристрою зі статичними параметрами.

Практична значимість. Використання перетворювача „стала напруга - сталий струм“ дозволяє оптимізувати обсяг споживання реактивної потужності та оплату за неї, а також покращує електромагнітну сумісність печі.

Ключові слова: флікер, реактивна потужність, динамічна компенсація, дугова сталеплавильна піч

\section{Особенности потоков реактивной мощности в схеме питания дуговой сталеплавильной печи с улучшенной электромагнитной совместимостью}

\author{
А. А. Малиновский ${ }^{1}$, В. Г. Турковский ${ }^{1}$, А. З. Музычак ${ }^{1}$, \\ Ю. В. Турковский
}

1 - Государственное высшее учебное заведение Национальный университет „Львовская политехника“, г. Львов, Украина, e-mail: malinowski@polynet.lviv.ua; volodtur@gmail.com; mAndriy@polynet.lviv.ua

2 - Физическое лицо предприниматель, г. Львов, Украина

Цель. Предложить использование для питания дуговых сталеплавильных печей переменного тока преобразователя с характеристикой „неизменный ток - неизменное напряжение“.

Методика. Для определения параметров режима установки использовалась программируемая среда MatLab Simulink с матричным формированием уравнений электромагнитного состояния. Усредненные за определенный интервал работы печи значения координат режима рассчитывались с учетом стохастического характера нагрузки на основе положений теории вероятности.

Результаты. Показано, что использование описанного выше преобразователя позволяет выбрать желаемый объем перетоков реактивной мощности между электрической сетью и печной установкой и обеспечивает, за счет поддержания неизменного тока в рабочих режимах, практически неизменное значение потока реактивной мощности. В результате существенно уменьшаются колебания напряжения в сети и выравниваются загрузки фаз. Показана возможность поддержания в рабочих режимах печи установившегося значения потребления реактивной мощности и возможность влиять на перетоки этой мощности.

Научная новизна. Показана возможность осуществления динамической компенсации реактивной мощности дуговой печи с помощью устройства со статическими параметрами.

Практическая значимость. Использование преобразователя „неизменный ток - неизменное напряжение“ позволяет оптимизировать объем потребления реактивной мощности и оплату за нее, а также улучшает электромагнитную совместимость печи.

Ключевые слова: фликер, реактивная мощность, динамическая компенсация, дуговая сталеплавильная печь

Рекомендовано до публікації докт. техн. наук К. М. Василівом. Дата надходження рукопису 12.01.18. 